\title{
The Impact of Government Subsidies on Business Per- formance Based on the Experience Data of China's GEM Listed Companies
}

\author{
Tiantian Zhao ${ }^{1, *}$ \\ ${ }^{1}$ School of Economics and Management, Beijing Jiaotong University, Haidian, Beijing 100044, China \\ *Corresponding author. Email: 19120685@bjtu.edu.cn
}

\begin{abstract}
In today's society, the Chinese government provides subsidized funds to listed companies for different motivations and reasons, and the theoretical research on the performance of the use of government subsidized funds is not comprehensive enough, and the conclusions are inconsistent. In order to reveal the performance and effectiveness of government subsidies for listed companies in China, this paper classifies the company's operating performance from two perspectives of financial performance and non-financial performance, based on the empirical data of China's GEM listed companies from 2012 to 2016.
\end{abstract}

Keywords: government subsidy, financial performance, non-financial performance, GEM

\section{INTRODUCTION}

In recent years, not only has the frequency of government subsidies for listed companies in China accelerated, but also the amount of subsidies has increased. According to Sohu Finance.com, using statistics from the Wind database, in the past 10 years, the Chinese government has issued a total of 190,000 subsidies of various types to 3,151 listed companies, with a total balance of 978.1 billion yuan. ${ }^{1}$ The GEM market, as a gathering place for high-tech emerging companies in China, has received strong financial support from the state. Table 1 shows the government subsidies in the GEM market. From the table, it can be seen that from 2012 to 2016, government subsidies showed a year-on-year increase in terms of total and average values, and the number of subsidized enterprises each year continued to increase. From 2012 to 2016, the total amount of government subsidies jumped from 3.532 billion yuan to 10.584 billion yuan. In 2016, there were 607 GEM listed companies in China, and the GEM government subsidy coverage rate was $98.5 \%$.

Table 1 Government Subsidies for GEM Listed Companies

\begin{tabular}{cccccc}
\hline Year & Number of companies & Min & Max & Average & Total (Billion ) \\
\hline 2012 & 353 & 4000.00 & 100225116.03 & 10033417.58 & 35.32 \\
2013 & 378 & 65000.00 & 153894000.11 & 11103933.11 & 41.97 \\
2014 & 418 & 129436.36 & 155579340.49 & 11779071.47 & 49.12 \\
2015 & 496 & 99062.44 & 383265810.48 & 15490831.83 & 76.83 \\
2016 & 598 & 64741.86 & 445211022.22 & 17699424.04 & 105.84 \\
\hline
\end{tabular}

Can such a strong government subsidy meet the expectations of the company's operating performance? Therefore, the research question in this article is: Can government subsidies improve the operating performance of listed companies and achieve government subsidy benefits?

In the existing literature, the research of government subsidies on business performance is mainly focused on the study of financial performance, and the selection of business performance indicators is singular. In this paper, the evaluation of business performance is divided into two perspectives: financial performance and non-financial performance. The return on net assets and non-financial performance are mainly from the perspective of the government: promoting technological research, promoting employment and promoting fiscal revenue, and studying whether government subsidies can improve corporate management and social performance.

\footnotetext{
${ }^{1}$ Source: http://www.sohu.com/a/197161333_473276
} 


\section{THEORETICAL ANALYSIS AND RE- SEARCH HYPOTHESES}

\subsection{Financial Performance Perspective}

Government subsidies help to alleviate the financial pressure of enterprises to a certain extent, and are beneficial to the normal production and operation of enterprises. At the micro-company level, Zang Zhipeng (2015) believes that the central and local governments can enrich their disposable cash flow through fiscal appropriations, financial subsidies, tax rebates, and tax cuts, thereby reducing the company's operating costs and improving its profitability. Therefore, the government subsidy can improve the company's direct financial performance to a certain extent, but it has a lagging effect on the company's financial performance. [1] Wang Wei and Li Haozhan (2017) take the panel data of listed companies in the new energy automobile industry from 2010 to 2015 as a sample, and the research results show that government subsidies are positively related to the financial performance of companies lagging behind. [2] From the perspective of the capital market, government subsidies can be regarded as "endorsement" for the credit of enterprises. The information transmitted by this endorsement effect can be used as a project evaluation standard for external investors such as banks (Liang Biming, Wang $\mathrm{Na}$, 2018). [3] Therefore, government subsidies can guide potential investors in enterprises to invest to a certain extent, and can effectively improve the company's financial performance on the basis of effectively reducing information asymmetry between enterprises and investors. Based on the above analysis, this article proposes hypothesis 1 :

H1: Government subsidies have a positive effect on the financial performance of GEM listed companies, but they have a certain lag.

\subsection{Non-financial Performance Perspective}

Relevant research shows that according to the motivation analysis of government subsidies, they are mainly promoting employment, technical research, government fiscal revenue and regional economic development (Huan Xiang, Huang Pengxiang, 2017). [4] In order to further understand the economic consequences and impact of government subsidies on listed companies and the effect of government subsidies, this chapter defines the non-financial social performance of companies from the perspectives of investment in research and development, employment effects, and promotion of fiscal revenue.

\subsubsection{Promote technology $R \& D$ and innovation}

Most of China's research on the effects of government R\&D subsidies supports government $R \& D$ subsidies to reduce the external effects of technology R\&D and encourage companies to invest in technology. Zhou Yikun (2012) studied a sample of strategic emerging industry companies in China and found that the amount of R\&D subsidies is positively related to the $R \& D$ investment and corporate costs that companies can observe. [5] Zhai Haiyan et al. (2015) believe that government subsidies have an incentive effect on enterprise R\&D investment in the short term. [6] In addition, the GEM is mainly oriented to independent innovation enterprises and other growth-oriented startup companies, mainly high-tech, high-growth, new Economy, new services, new agriculture, new energy, new materials, new business model companies, so hypothesis 2 :

$\mathrm{H} 2$ : Government subsidies have a positive effect on the R\&D and innovation performance of GEM listed companies

\subsubsection{Employment promotion perspective}

At present, there are few empirical studies on the impact of government subsidies on employment. In 2019, Pan Hongbo and Li Danyu used 2007-2016 Chinese A-share listed companies as a sample study to find that companies with many employees and good treatment would receive more government subsidies when encouraged by industrial policies, but this was mainly reflected in the next period. [7] The specific reasons are as follows: (1) The government's special employment subsidy helps reduce the cost of recruiting and training new employees; (2) The government subsidy can increase the company's current cash flow, alleviate the problem of capital shortage, reduce the risk of scientific research investment, and increase the increase of enterprises. Capital expenditures and enthusiasm for new projects are driving companies to hire more employees. Based on the above analysis, this article proposes research hypothesis 3:

H3: The more government subsidies obtained, the better the employment promotion effect of GEM listed companies lagging behind.

\subsubsection{Employment promotion perspective}

Part of Huang Xiang and Huang Pengxiang's (2017) research involved the study of the social benefits of government subsidies. The research results show that government subsidies and tax indicators show a significant positive correlation. [8] Government subsidies can indirectly promote enterprises to increase tax payment and thereby increase regional fiscal revenue, especially the high development potential of listed companies on GEM. Based on this, put forward hypothesis 4 :

H4: The more government subsidies received, the more fiscal revenue the listed company provides to the government.

\section{RESEARCH DESIGN}

The sample scope of this article is the data of A-share listed companies from 2012 to 2016, excluding special industries 
such as financial insurance, excluding ST and *ST corporate data from 2012 to 2016, and excluding listed companies with missing or abnormal relevant information during the statistical period. csmar.

\subsection{Model Design}

The basic model is as follows:

$Y=\alpha+\beta X+\sum_{k=1}^{\theta} \theta_{k}$ Control $+\varepsilon$

In the formula: $Y$ - explained variables (financial performance and non-financial performance);

$X$ - Explanatory variables (government subsidies);

Control - Control variables.

\subsection{Variable Definitions}

The variable explained in this article is the total government subsidy. From the analysis above, the influence of government subsidies on corporate financial performance has a lag effect. Lu Guoqing (2014) uses the sum of government subsidies of the current year and $85 \%$ of government subsidies of the previous year to measure the government considering lag effects Subsidies, [9] This article uses this measurement method to verify and analyze the financial performance of enterprises. For the measurement of non-financial performance, this article uses the current government subsidy to total assets ratio as the current variable, namely, Gov. According to the related literature research, the definitions of other variables in this paper are shown in Table 2.

Table 2 Variable definition table

\begin{tabular}{|c|c|c|c|}
\hline & Variable name & Symbol & Definition \\
\hline \multirow{4}{*}{$\begin{array}{l}\text { Explained } \\
\text { variable }\end{array}$} & Financial performance & $R O E$ & Net profit in period $t$ / owner equity in period $t$ \\
\hline & $\begin{array}{l}\text { R\&D innovation perfor- } \\
\text { mance }\end{array}$ & $R D$ & Total research and development expenditure / main business income \\
\hline & $\begin{array}{l}\text { Employment effect per- } \\
\text { formance }\end{array}$ & Staff & Total number of employees in period $t$ / main business income in period $t$ \\
\hline & $\begin{array}{l}\text { Fiscal revenue perfor- } \\
\text { mance }\end{array}$ & Taxrate & Total tax expenditures in period $\mathrm{t} /$ total assets in period $\mathrm{t}$ \\
\hline \multirow{2}{*}{$\begin{array}{l}\text { Explanatory } \\
\text { variables }\end{array}$} & Government subsidy 1 & Gs & $\begin{array}{c}\text { (Government subsidy in period } \mathrm{t}+\text { government subsidy in period } \mathrm{t}-1 * 85 \%) / \\
\text { Total assets (Applicable financial performance assumptions) }\end{array}$ \\
\hline & Government subsidy 2 & Gov & $\begin{array}{l}\text { Government subsidies in period } \mathrm{t} / \text { total assets in period } \mathrm{t} \\
\text { (Applying non-financial performance assumptions) }\end{array}$ \\
\hline \multirow{8}{*}{$\begin{array}{l}\text { Control } \\
\text { variable }\end{array}$} & Enterprise size & Size & Natural logarithm of total assets at the end of the year \\
\hline & Solvency & Debt & Total Liabilities / Total Assets \\
\hline & Development ability & Growth & $\begin{array}{c}\text { (Total assets in period t-total assets in period t-1) / total assets in the previous } \\
\text { period }\end{array}$ \\
\hline & Operating capacity & Assetto & Total asset turnover in period $\mathrm{t}$ \\
\hline & Tax burden & $\operatorname{Tax}$ & $\begin{array}{l}\text { Log of corporate income tax in period t } \\
\text { (Applicable to financial performance and R\&D performance models) }\end{array}$ \\
\hline & Wages and benefits & Wage & $\begin{array}{l}\text { Total wages and benefits / total employees } \\
\text { (Applicable Employment Performance Model) }\end{array}$ \\
\hline & Capital intensity & Cpint & Fixed assets / total assets (Applicable fiscal revenue performance model) \\
\hline & Inventory intensity & Invint & $\begin{array}{l}\text { Total Inventory / Total Assets } \\
\text { (Applicable fiscal revenue performance model) }\end{array}$ \\
\hline
\end{tabular}

\section{EMPIRICAL TEST}

\subsection{Hypothetical Test}

In order to eliminate the influence of extreme values, this paper performed a $5 \%$ extreme value tailing on the original data before the main test regression. In addition, after the Hausman test, a fixed effect model should be used instead of a random effect model. 
Table 3 Empirical test results

\begin{tabular}{|c|c|c|c|c|}
\hline & $\begin{array}{l}\text { Financial performance } \\
\text { (ROE) }\end{array}$ & $\begin{array}{l}\text { R\&D innovation per- } \\
\text { formance }(\mathrm{RD})\end{array}$ & $\begin{array}{l}\text { Employment effect } \\
\text { performance (Staff) }\end{array}$ & $\begin{array}{l}\text { Fiscal revenue perfor- } \\
\text { mance (Taxrate) }\end{array}$ \\
\hline Gs & $0.8047606 * * *$ & & & \\
\hline Gov & & $27.04218 * * *$ & 0.0213244 & $0.2672102 * * *$ \\
\hline Size & $-0.0245879 * * *$ & $-0.4931484 * *$ & $-0.003279 * * *$ & $-0.0011604 * *$ \\
\hline Debt & $0.0169713^{*}$ & $-1.101083^{*}$ & $-0.003279 * *$ & $-0.0052527 * *$ \\
\hline Growth & $0.0217075 * * *$ & -0.1823456 & -0.0004387 & $-0.0081257 * * *$ \\
\hline Assetto & $0.1103098 * * *$ & $-7.093464 * * *$ & $-0.0058231 * * *$ & $0.0393629 * * *$ \\
\hline $\operatorname{Tax}$ & $1.80 \mathrm{e}-09 * * *$ & $-1.66 \mathrm{E}-08 * *$ & & \\
\hline Wage & & & $-2.11 \mathrm{E}-08 * * *$ & \\
\hline Cpint & & & & $-0.0118212 * * *$ \\
\hline Invint & & & & -0.0092059 \\
\hline _cons & $0.4954922 * * *$ & $20.93126 * * *$ & $0.0918824 * * *$ & $0.0405184 * * *$ \\
\hline
\end{tabular}

From Table 3, we can know that the influence coefficient of government subsidies on the financial performance of listed companies on GEM is 0.805 , and it is significant at the level of $1 \%$. Because the calculation of Gs takes into account the lagging effect of government subsidies, it verifies the government subsidies in the previous article. Theoretical analysis of the impact of corporate financial performance and the results of Hypothesis H1. Small scale and simple organizational structure are the distinctive characteristics of GEM listed companies compared to other financial market listed companies. Therefore, GEM listed companies can more flexibly respond to opportunities arising from operating conditions by virtue of their advantages in this regard. It may be difficult, and it can be seen from this that GEM listed companies will use government subsidies more efficiently. In addition, the types of subsidies given by the government to GEM listed companies tend to be R\&D and innovation or support emerging industries, according to statistics. As of the end of 2016, national high-tech industrial companies have reached $95 \%$ of GEM listed companies, and more than $70 \%$ of the company's business areas involve emerging industries. ${ }^{2}$ These listed companies have achieved rapid development with government policy support. The empirical results also fully prove that government subsidies have a positive impact on the financial performance of GEM listed companies.

The government subsidy has an impact coefficient of 27.04 on $R \& D$ and innovation, and passed the significance test. Government subsidies have a significant promotion effect on the investment in research and development of listed companies. The more government subsidies a listed company receives, the more investment in research and development. The government subsidies have a significant effect on investment in research and development. Therefore, the hypothesis $\mathrm{H} 2$ studied in this paper is confirmed. The research of Chinese scholar Chen Xudong (2018) once believed that certain $R \& D$ innovation investment of enterprises has an important impact on the operation and development of enterprises, but the rate of return on R\&D expenditure varies in different industries. [10] For high-tech industries, the impact of R\&D expenditure on corporate performance is greater and more significant. And most of China's GEM market is high-tech enterprises from the nextgeneration information technology, new materials, new energy, high-end equipment manufacturing and other industries. Therefore, GEM listed companies can often make better use of government subsidy funds for R\&D and innovation activities.

The influence coefficient of government subsidies on GEM listed companies on employment performance is positive, but they have not passed the significance test. However, it also shows to a certain extent that government subsidies cannot increase the number of employees in the current period, but they can promote the employment promotion effect of the next year. Hypothesis $\mathrm{H} 3$ is confirmed. The reason may be that the government subsidy can increase the company's current cash flow and increase the company's net profit. It cannot directly affect the company's operating activities, but the economic benefits flowing into the company can have a positive impact on the company's operating capacity in the coming year. In the next year, it may be more willing to expand reproduction, resulting in government subsidies that year that have a positive role in promoting the employability of listed companies in the second year.

The influence coefficient of government subsidies on the tax expenditure of start-up listed companies is and is significant at the level of $1 \%$, assuming $\mathrm{H} 3$ is confirmed. It reflects that Chinese listed companies have effectively

\footnotetext{
${ }^{2}$ Source: http://www.chinanews.com/stock/2016/10-27
} 
Fourth, there is a significant positive correlation between government subsidies for GEM listed companies and tax expenditures of Chinese enterprises, reflecting that Chinese listed companies effectively promote corporate tax expenditures through government subsidies and help increase fiscal revenue at all levels of government.

\section{REFERENCES}

[1] Zang Zhipeng. Research on the relationship between government subsidies, corporate nature and operating performance of listed companies in cultural industries: an empirical analysis based on panel data from 2011 to 2013 [J]. Modern Management Science, 2015, (3): 48-50. DOI: 10.3969 / j.issn. 1007-368X.2015.03.016.

[2] Wang Wei, Li Haozhan, Qiao Penghua, et al. Research on the impact of government subsidy methods on the performance of new energy automobile companies: an in-depth analysis based on the growth of the company [J]. Science \& Technology Progress and Policy, 2017, 34 (23): 114- 120. DOI: 10.6049 / kjjbydc.201708X082.

[3] Liang Biming. Research on the influence of government subsidies on the investment direction of listed companies [J]. Friends of Accounting, 2018,0 (4): 32-37.DOI: 10.3969 / j.issn.1004-5937.2018.04.008.

[4] Huang Xiang. Research on the main motivation of government subsidized enterprises: an empirical test based on the panel data of A-share listed companies in China [J]. Western Forum, 2017,27 (3): 106-116.DOI: 10.3969 / j. issn.1674-8131.2017.03.012.

[5] Zhou Yikun. Strategic emerging industry innovation game, R \& D spillovers and government subsidies [J]. Journal of Shenzhen University (Humanities and Social Sciences), 2012, 29 (5): 55-59. DOI: 10.3969 / j.issn. 1000260X.2012.05.008.

[6] Zhai Haiyan, Dong Jing, Wang Jiangping. The Impact of Government Science and Technology Funding on Enterprise R \& D Investment_ A Study Based on the Heckman Sample Selection Model [J]. Research and Development Management, 2015, 27 (5): 34-43. DOI: 10.3969 / j.issn. 1004-8308.2015.05.004.

[7] Pan Hongbo, Li Danyu. Industrial policies, corporate employees and government subsidies [J]. Macro Quality Research, 2019, 7 (1): 17-30. DOI: 10.13948 / j.cnki.hgzlyj.2019.01.003.

[8] Huang Xiang, Huang Pengxiang. Research on the main motivations of government subsidized enterprises: an empirical test based on the panel data of China's A-share listed companies [J]. Western Forum, 2017,27 (3): 106-116. DOI: 10.3969 / j.issn.1674-8131.2017.03.012.

[9] Lu Guoqing, Wang Zhou, Zhang Chunyu. Research on the Performance of Government Innovation Subsidies for 
Strategic Emerging Industries in China [J]. Economic Research, 2014, 49 (7): 44-55.

[10] Chen Xudong, Mu Xueying. The Impact of Government Subsidies on the Performance of Science and Technology Innovation Enterprises: Taking GEM Listed Companies as an Example [J]. Science \& Technology Progress and Policy, 2018, 35 (12): 85-91. DOI: 10.6049 / kjjbydc. 2017090605. 